\title{
Binary Solvent Dispersive Liquid-Liquid Microextraction for the Determination of Pesticides in Natural Water Samples
}

\author{
Priscila L. S. Estevão, ${ }^{a}$ Patricio Peralta-Zamora ${ }^{*, a}$ and Noemi Nagata ${ }^{a}$ \\ ${ }^{a}$ Departamento de Química, Universidade Federal do Paraná, \\ P.O. Box 19081, 81531-990 Curitiba-PR, Brazil
}

\begin{abstract}
A binary solvent dispersive liquid-liquid microextraction (BS-DLLME) technique was developed for simultaneous determination of diuron, teflubenzuron, atrazine, and two of its metabolites (desisopropylatrazine and desethylatrazine) in natural waters. The extraction was investigated using a three components mixture design to determine the best ratio between the extractors (dichloromethane and chloroform) and the disperser solvent (acetonitrile). According to the analysis of variance, empirical response surfaces were obtained for each analyte, correlating the absolute recovery and the mixture composition. The analysis of the overlapping surfaces allowed the detection of the best condition for the analytes extraction: $481 \mu \mathrm{L}$ of chloroform, $56.6 \mu \mathrm{L}$ of dichloromethane, $906 \mu \mathrm{L}$ of acetonitrile, $5.00 \mathrm{~mL}$ of the aqueous sample, and $10 \%(\mathrm{~m} / \mathrm{v})$ of sodium chloride. The proposed method was validated and successfully applied in the analysis of surface waters, presenting suitable linearity $(r>0.9990)$, low limits of detection $\left(0.015\right.$ to $\left.0.36 \mu \mathrm{g} \mathrm{L}^{-1}\right)$ and quantification ( 0.049 to $\left.1.2 \mu \mathrm{g} \mathrm{L}^{-1}\right)$, and relative recoveries between 84.8 and $106.1 \%$.
\end{abstract}

Keywords: binary solvent dispersive liquid-liquid microextraction, pesticides, natural waters, mixture design

\section{Introduction}

In the last years, the focus of the environmental monitoring has been directed to a large group of organic pollutants, ${ }^{1}$ many of which can produce harmful effects at low concentration such as endocrine disruption. ${ }^{2}$ In the context of endocrine disrupting compounds (EDCs), it is relevant to remark the use of pesticides, herbicides, insecticides, and fungicides, in the pest control in agriculture. When applied to crops, these compounds can be transported over long distances via different mechanisms, especially precipitation, leaching, volatilization, and surface water runoff. Therefore, pesticides drift into aquatic environments contaminating ground and surface waters. ${ }^{3}$

Between 2008 and 2013, Brazil stood out as the world's largest consumer of pesticides, ${ }^{4,5}$ due to the intensive agricultural production, given prominence to grains crops like corn, soybeans, and wheat. Therefore, atrazine (ATZ), diuron (DIU), and carbendazim, which are allowed in these crops, are frequently among the top-ten most sold active ingredients in Brazil. ${ }^{6}$ As a consequence of the high consumption and the inadequate use and residual disposal,

*e-mail: zamora@ufpr.br the contamination of surface and consumption waters has already been reported in several Brazilian states, especially in areas of high agricultural production. ${ }^{7-9}$

In general, these chemical species show high toxicity and persistence in the environment, which justifies the efforts dedicated to establish routines that allow their quantification in environmental matrices. Several techniques have been employed for pesticides determination in water samples, ${ }^{10}$ such as solid phase extraction (SPE), ${ }^{11,12}$ stir bar sorptive extraction (SBSE), ${ }^{13,14}$ and liquid-phase microextraction (LPME) ${ }^{15}$ techniques, such as the dispersive liquid-liquid microextraction (DLLME). ${ }^{16-19}$ Developed by Rezaee et al..$^{20}$ in 2006, the DLLME is a rapid extraction method that provides high recovery rates (especially for non-polar analytes), ease of operation, and also low cost, which is a feature inherent to all liquid-liquid extractions (LLE).

Several changes have been introduced to DLLME, ${ }^{21-27}$ some aiming to overcome the recovery problems in the simultaneous determination of analytes with broad polarity range. For instance, the use of two or three extractor solvents has been implemented by several authors. ${ }^{28-32}$ Such modifications can notably improve the extraction of organic polar analytes, which is difficult to achieve 
by employing the conventional LLE procedures because of the difficulty of finding an adequate solvent system. Wang et al. ${ }^{29}$ employed $100 \mu \mathrm{L}$ of chloroform:undecanol (1:1) for the determination of nicotine (log Kow 1.17) and cotinine (log Kow 0.07) in urine using DLLME with the solidification of a floating organic drop (SFO). If compared to the isolated use of the solvents, the recovery of cotinine, which is the most polar analyte in the system, was improved. Farajzadeh and Khoshmaram ${ }^{30}$ were the first to use a ternary solvents mixture to evaluate the migration of phthalates (log Kow 1.6 to 6.6) from plastic food packaging. The extractor solvent mixture included chloroform (CLF, $404 \mu \mathrm{L}$ ), dichloromethane (DCM, $122 \mu \mathrm{L}$ ) and carbon tetrachloride ( $44 \mu \mathrm{L}$ ), and $2 \mathrm{~mL}$ of dimethylformamide as the disperser solvent. Under optimized conditions, the absolute recoveries (ARs) varied from $20-90 \%$, for samples of mineral water, lemon juice, dough, vinegar, yogurt, and soda.

This study evaluates the potential of DLLME in the extraction of pesticides of different polarities, using a binary extractor solvent system (chloroform and dichloromethane), and acetonitrile $(\mathrm{ACN})$ as a disperser solvent. The selected pesticides were: diuron (DIU, phenyl urea herbicide, $\log \mathrm{K}_{\text {ow }} 2.9$ ), teflubenzuron (TFB, benzoylurea insecticide, $\log \mathrm{K}_{\mathrm{ow}} 4.3$ ), atrazine (ATZ, triazine herbicide, $\log \mathrm{K}_{\mathrm{ow}} 2.7$ ) and its two main metabolites, desisopropylatrazine (DIA, $\log \mathrm{K}_{\mathrm{ow}} 1.1$ ) and desethylatrazine (DEA, $\log$ Kow 1.5). The effect of the solvent mixture composition was evaluated using a mixture design, which is a statistical tool that allows evaluating several variables simultaneously and also to investigate the interaction between them, ensuring the optimization with a smaller number of experiments. ${ }^{33}$ This kind of experimental design allows the measurement of the effect of different mixture compositions in the response of interest. The proportions of the constituents in the mixture are mutually dependent and the sum of the components is limited to $100 \%$. The mixture design is broadly applied in the pharmaceutical industry, in food analysis, ${ }^{34,35}$ and in the optimization of experiments such as the solvent extraction of bioactive compounds from natural products ${ }^{36,37}$ and in sample preparation. . $29,30,38^{2}$

\section{Experimental}

\section{Reagents}

All standards were purchased from Sigma-Aldrich with purity higher than $96 \%$. Stock solutions of each analyte were prepared in methanol (HPLC grade, 99.99\%, J.T.Baker, Phillipsburg, USA) in a concentration of $100 \mathrm{mg} \mathrm{L}^{-1}$, and were kept under refrigeration at $-20^{\circ} \mathrm{C}$. From these stock solutions, working solutions were freshly prepared by appropriate dilution of the initial mobile phase composition in ultrapure water $(18.2 \mathrm{M} \Omega \mathrm{cm}$, Millipore Simplicity UV, Bedford, MA, USA). HPLC grade solvents used as extractor solvents were chloroform and dichloromethane (99.99\%, Sigma-Aldrich, St. Louis, USA), and the one used as a disperser solvent was acetonitrile (99.99\%, J.T.Baker, Phillipsburg, USA). Sodium chloride was puriss p.a. grade ( $\geq 99.8 \%$, Sigma-Aldrich, St. Louis, USA).

\section{Chromatographic analysis}

The chromatographic analyses were carried out on a high-performance liquid chromatography (LC) Varian 920-LC (Mulgrave, Australia), equipped with an autosampler, quaternary gradient pump, diode array detector (DAD) and GALAXIE software v 1.9. The chromatography separation was carried out on a C18 analytical column $(250 \times 4.6 \mathrm{~mm}, 5 \mu \mathrm{m}$ particle size, Microsorb-MV100-5) with a $\mathrm{C} 18$ guard column. The sample injection volume was set at $50 \mu \mathrm{L}$, the flow rate was $1.0 \mathrm{~mL} \mathrm{~min}^{-1}$, and the column temperature was kept at $40^{\circ} \mathrm{C}$. The gradient elution mode was developed for the simultaneous determination of the analytes using acetonitrile:water $(\mathrm{v} / \mathrm{v})$. The initial mobile phase composition (40:60 acetonitrile:water) was kept constant for the first $8 \mathrm{~min}$, then was linearly altered to $90 \%$ of acetonitrile at $15 \mathrm{~min}$ remaining at this composition until $20 \mathrm{~min}$, and linearly returned to the initial conditions at $23 \mathrm{~min}$. External analytical curves were elaborated using the mobile phase (40:60 acetonitrile:water) as solvent, in the concentration range of 2.5 to $2500 \mu \mathrm{g} \mathrm{L}^{-1}$. The DAD monitoring wavelengths were $215 \mathrm{~nm}$ for DIA and DEA, $223 \mathrm{~nm}$ for ATZ, $254 \mathrm{~nm}$ for DIU, and $200 \mathrm{~nm}$ for TFB.

\section{Extraction procedure}

Two mixture designs were performed to evaluate the best solvents composition (CLF, DCM, ACN in percentage) for the extraction of the analytes. Due to the different densities of the solvents employed (CLF $1.48 \mathrm{~g} \mathrm{~mL}^{-1}$; DCM $1.33 \mathrm{~g} \mathrm{~mL}^{-1}$; ACN $0.786 \mathrm{~g} \mathrm{~mL}^{-1}$ ), the proportions of the solvent mixtures were evaluated considering their mass and not their volume, setting $100 \%$ as $1.500 \mathrm{~g}$ of the extractor and disperser mixture solvents. The proportions used in each design are shown in Figure 1, and the response (absolute recovery of each analyte) was evaluated in Statistica software. ${ }^{39}$

Assays were performed in $15 \mathrm{~mL}$ polypropylene tubes (Kasvi, K19-0015, Curitiba, Brazil), using a micropipette to add the appropriated volume of extractor and disperser solvents to $5.00 \mathrm{~mL}$ of a standard aqueous solution fortified 

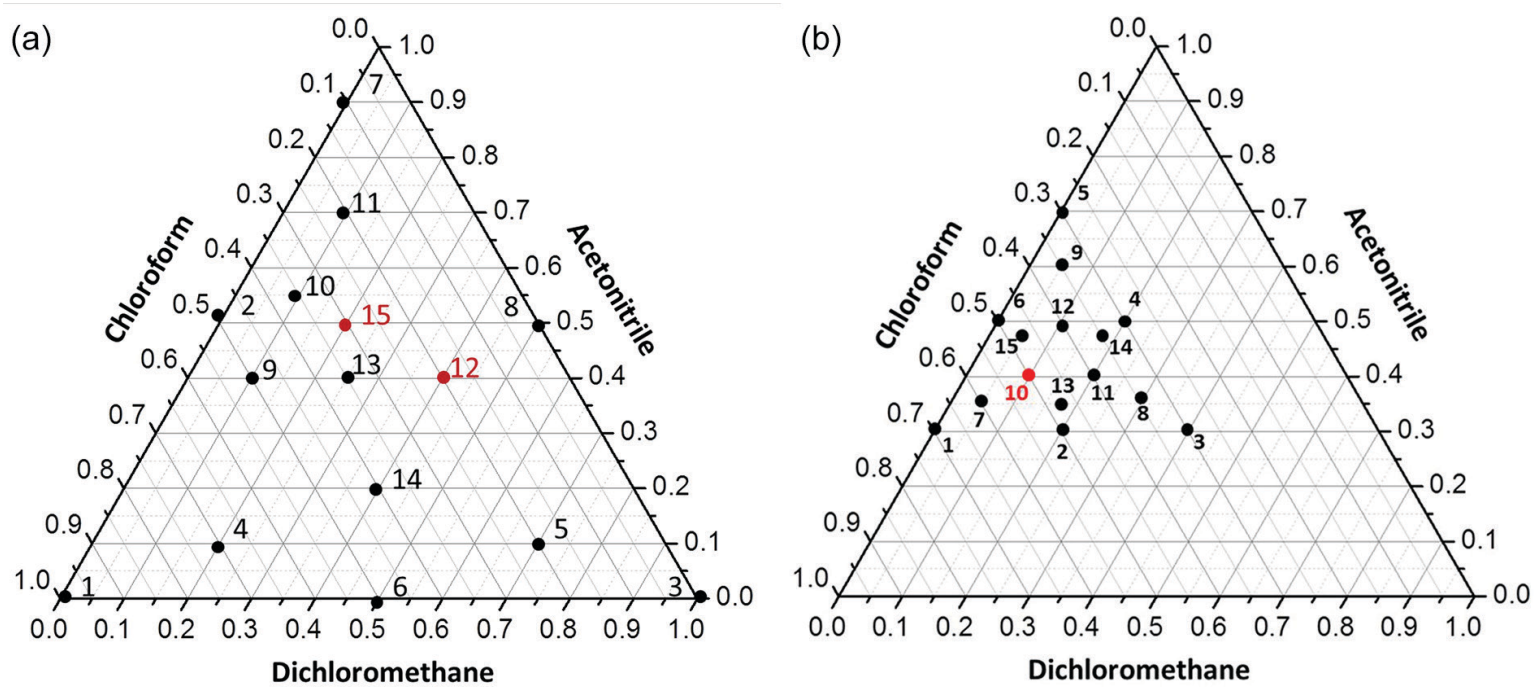

Figure 1. Mass proportions employed in the mixture designs. (a) Design 1: general mixture design with triplicate of points 15 and 12; (b) design 2: restricted mixture design with triplicate of point 10 .

with $30.0 \mu \mathrm{g} \mathrm{L} \mathrm{L}^{-1}$ of each analyte. These solutions were prepared in $10 \%(\mathrm{~m} / \mathrm{v})$ sodium chloride to raise the ionic strength and facilitate the phase separation due to the salting-out effect. ${ }^{17,18}$ Quantities of salt higher than $10 \%$ were not used, due to the precipitation of small crystals of $\mathrm{NaCl}$ in the interface between the organic and the aqueous phases after the centrifugation step.

The samples were vortexed (B. Braun Biotech International Vortex Certomat MV, Melsungen, Germany) for $30 \mathrm{~s}$ and then centrifuged for $6 \mathrm{~min}$ at $4400 \mathrm{rpm}$ (Eppendorf centrifuge 5702, Hamburg, Germany). The vortex agitation was set at $30 \mathrm{~s}$ since the simple solvent addition with the micropipette did not present reproducible results in preliminary tests. Also, the speed and time of centrifugation were previously optimized in order to promote the complete phases separation. Afterwards, all sediment phase was collected with a glass syringe, transferred to a $2 \mathrm{~mL}$ vial, dried under a gentle flow of nitrogen, re-dissolved in $250 \mu \mathrm{L}$ of mobile phase (ACN: $\mathrm{H}_{2} \mathrm{O}, 40: 60$ ), and analyzed by LC-DAD.

After the optimization by mixture design, the effect of the total solvent mass on the pesticides recovery was performed employing $0.800 ; 1.00 ; 1.25 ; 1.50 ; 1.75$ and $2.00 \mathrm{~g}$ of the solvent mixture, keeping agitation, centrifugation, drying and re-dissolving conditions as previously described.

\section{Real sample analysis}

Spring water (latitude: $24^{\circ} 48^{\prime} 31.8^{\prime \prime}$; longitude: $50^{\circ} 03^{\prime} 11.9^{\prime \prime}$ ) and river sample (Iapó River, latitude 2441'07.0"; longitude: 4952'13.8') were collected in Castro City (east of Paraná State, Brazil). All the samples were filtered through $0.45 \mu \mathrm{m}$ glass fiber membrane
(Macherey-Nagel, Düren, Germany), added with $1 \mathrm{~mL} \mathrm{~L}^{-1}$ of methanol to avoid the microorganisms proliferation, and stored in brown glass bottles at $4{ }^{\circ} \mathrm{C}$ before analysis. After filtration, the soluble fractions were analyzed by the optimized method. The samples were fortified with six different levels of each analyte $\left(0.50-100 \mu \mathrm{g} \mathrm{L}^{-1}\right.$, $\mathrm{n}=3$ ) by adding the appropriate volume of the stock solutions. The fortified samples were submitted to the binary solvent-dispersive liquid-liquid microextractionliquid chromatography with diode array detection (BS-DLLME-LC-DAD) method in up to $48 \mathrm{~h}$ to perform the matrix-matched calibration. Matrix-matched calibration was performed in both real samples and in ultrapure water, at the same fortification levels.

\section{Results and Discussion}

\section{Chromatographic analyses and standard calibration}

The analytes were separated by LC-DAD (Figure 2) on a $\mathrm{C} 18$ column under acetonitrile:water gradient elution with a suitable resolution. The quantification was performed via external standard calibration $(n=3)$ using independent curves prepared in the gradient initial composition (40:60, acetonitrile:water). The detectability of the chromatographic method was evaluated using the external analytical curves (Table 1). The linear range (LR) is comprised between the instrumental limit of quantification (LOQ) and the upper limit of the calibration curve. The limits of detection (LOD) and quantification (LOQ) were estimated by the ratio between the standard deviation of the intercept (s) and the slope of the analytical curves (S), being LOD equal to 3 times 
and LOQ to 10 times the s/S ratio. Low instrumental limits of detection $\left(\mathrm{LOD}_{\mathrm{i}}<3.0 \mu \mathrm{g} \mathrm{L}-1\right)$ and quantification $\left(\mathrm{LOQ}_{\mathrm{i}}<10.0 \mu \mathrm{g} \mathrm{L}^{-1}\right)$ were achieved, similar to those described in the literature, ${ }^{40-43}$ recalling that until then, no preconcentration step was performed. Furthermore, suitable linearity $(r>0.9997)$ was obtained in the studied LR for all compounds. The analytical curves presented a random dispersion of the residuals and significant regression with the ratio of the regression sum of squares (SSR) by the sum of squared residuals ( $\mathrm{SSr}$ ) superior to the $F_{\text {critical }}$, according to the analysis of variance (ANOVA) with $95 \%$ of confidence level. The absolute recoveries, used as response in the DLLME method optimization, were estimated utilizing the external standardization curves.

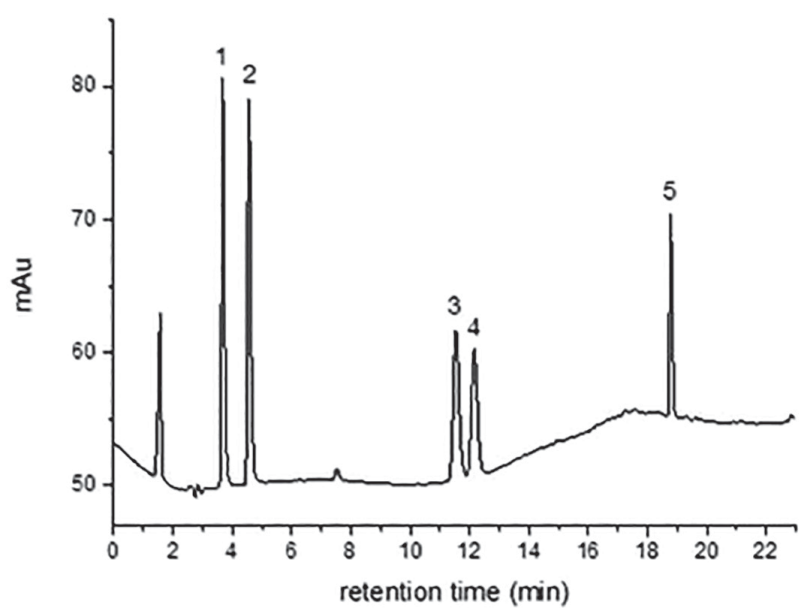

Figure 2. Typical LC-DAD chromatogram $(215 \mathrm{~nm})$ of the analytes standards mixture $\left(500 \mu \mathrm{g} \mathrm{L}^{-1}\right)$. 1: Desisopropylatrazine; 2 : desethylatrazine; 3: atrazine; 4: diuron; 5: teflubenzuron.

\section{Binary solvent dispersive liquid-liquid microextraction} process

The conventional DLLME employs only one extractor solvent, what often hinders the simultaneous extraction of analytes with a wide range of polarity. Preliminary tests for the simultaneous pesticides extraction were performed using $n$-octanol, toluene, cyclohexane as extractor solvents, and four other disperser solvents, acetone, acetonitrile, methanol, and ethanol. However, better recoveries for the most polar analytes, DIA and DEA, were achieved by adding a more polar solvent, dichloromethane $\left(\log \mathrm{K}_{\mathrm{ow}} 1.5\right)$, to the extractor:disperser mixture solvents, which consisted of chloroform:acetonitrile (CLF $\log \mathrm{K}_{\text {ow }}$ 2.0:ACN $\log \mathrm{K}_{\mathrm{ow}}-0.33$ ). These tests were performed with $0.300 \mathrm{~mL}$ of CLF, $0.200 \mathrm{~mL}$ of DCM and $1.000 \mathrm{~mL}$ of $\mathrm{ACN}$, and absolute recoveries between 31 and $74 \%$ were obtained. Therefore, the extraction BS-DLLME routine was investigated applying a simplex design to determine the best ratio between the extractors (CLF and DCM) and the disperser $(\mathrm{ACN})$ solvents.

The simplex design is a kind of mixture design in which the components of the mixture are mutually dependent and their sum is limited to $100 \%{ }^{44}$ It allows the evaluation of the effect of different mixture compositions on the response. In the case of a three components mixture (CLF, DCM, ACN in percentage), different combinations are arranged in a triangle, whose vertices correspond to the pure components (100\%), the edges represent the binary mixtures, and the points inside the triangle to the ternary mixtures. Empiric models can be built by the least squares method, making it possible to estimate the response for a given composition of the mixture, provided that it is comprised in the experimental design.

The volume of solvent was converted to mass of solvent using the values for density, and it was possible to estimate the mass as $0.444 \mathrm{~g}$ of CLF; $0.265 \mathrm{~g}$ of DCM and $0.786 \mathrm{~g}$ of $\mathrm{ACN}$ employed in the preliminary test. Therefore, the total mass of solvent used was $1.495 \mathrm{~g}$, corresponding to a ratio in $\%(\mathrm{~m} / \mathrm{m})$ of $29.7 \% \mathrm{CLF}, 17.7 \% \mathrm{DCM}$, and $52.6 \% \mathrm{ACN}$. Hence, there were two mixture designs for three variables, and the $1.500 \mathrm{~g}$ of mixture solvents (CLF, DCM, ACN in percentage) was fixed at $100 \%$.

At this optimization step, the studied response was the absolute recovery (AR) of the analytes, estimated by the ratio between the observed $\left(\mathrm{C}_{\mathrm{o}}\right)$ and the expected concentration $\left(\mathrm{C}_{\mathrm{e}}\right)$ :

Table 1. Analytical parameters of external standard calibration and retention time of analytes

\begin{tabular}{lccccc}
\hline Analyte & Retention time / min & LR / $\left(\mu \mathrm{g} \mathrm{L}^{-1}\right)$ & $\mathrm{r}$ & Slope & $\mathrm{LOD}_{\mathrm{i}} /(\mu \mathrm{g} \mathrm{L}-1)$ \\
\hline DIA $(215 \mathrm{~nm})$ & 3.67 & $2.9-2500$ & 0.9998 & 0.00720 & 0.87 \\
DEA $(215 \mathrm{~nm})$ & 4.58 & $7.9-2500$ & 0.9999 & 0.00475 & 2.4 \\
ATZ $(223 \mathrm{~nm})$ & 11.59 & $4.9-2500$ & 0.9996 & 0.00635 & 1.5 \\
DIU $(254 \mathrm{~nm})$ & 12.31 & $10.0-2500$ & 0.9997 & 0.00277 & 3.0 \\
TFB $(200 \mathrm{~nm})$ & 18.84 & $7.6-2500$ & 0.9993 & 0.00487 & 2.3 \\
\hline
\end{tabular}

LR: linear range; r: correlation coefficient; $\mathrm{LOD}_{\mathrm{i}}$ : instrumental limit of detection; DIA: desisopropylatrazine; DEA: desethylatrazine; ATZ: atrazine; DIU: diuron; TFB: teflubenzuron. 
$\mathrm{AR}=\frac{\mathrm{C}_{\mathrm{o}} \times 100}{\mathrm{C}_{\mathrm{e}}}($ reference 45$)$

$\mathrm{C}_{\mathrm{e}}=\frac{\mathrm{F}_{\mathrm{L}} \times \mathrm{V}_{\mathrm{s}}}{\mathrm{V}_{\mathrm{r}}}$

where $\mathrm{F}_{\mathrm{L}}$ is the concentration of the fortification level, $\mathrm{V}_{\mathrm{s}}$ is the volume of sample $(5.00 \mathrm{~mL})$, and $\mathrm{V}_{\mathrm{r}}$ is the volume of mobile phase redissolution $(0.250 \mathrm{~mL})$.

\section{Design 1}

The conditions employed in the first mixture modeling and the ARs obtained in each assay are shown in Figure 1a and described in Table 2. These compositions were selected to simultaneously evaluate the effect of the two extractors solvents without the disperser solvent (i.e., the points at the triangle vertices), the individual effect of the extractor solvent with the disperser solvent (i.e., points at the edges), and the effect of the combination of the two extractors solvents with the disperser solvent at different ratios (i.e., internal points in the diagram).

The assay 15, which has similar conditions to the preliminary test using CLF:DCM:ACN, was carried out in triplicate to estimate the variance, thus totaling 17 experiments. Phase separation was not obtained in the assay employing pure ACN.

In the absence of ACN (assay 2) it was not possible to recover any of the analytes in concentrations above the LOQ of the chromatographic method. This result shows the importance of the disperser to the rapid establishment of an equilibrium between the solvent phases, allowing adequate recoveries in short extraction times. ${ }^{46}$ In assays 1 and 3, satisfactory recoveries were obtained (> 70\%) for most analytes, in spite of the absence of the disperser. However, large quantities of CLF and DCM were employed: 1.01 and $1.13 \mathrm{~mL}$, respectively. Therefore, among all experiments, assay 15 allowed good recoveries for the analytes with relatively lower consumption of chlorinated solvents. Besides, a significant improvement in the analytes extraction was observed in this assay compared to the preliminary CLF:DCM:ACN assays, where no $\mathrm{NaCl}$ was employed, thus evidencing the salting-out effect. Nonetheless, good recoveries were observed in assays 10 and 13, which conditions are similar to those used in assay 15 , indicating that this region may present the best analyte extraction performance.

Furthermore, the difficulty of interpreting the individual results obtained in this design indicates the existence of an interaction between them. Thereby, the effect of the mixture components on the recoveries and the possibility of obtaining valid empirical models were assessed using an ANOVA with $95 \%$ of confidence level. However, valid models were not obtained due to the wide range of the mixture composition evaluated in this design. Therefore,

Table 2. Conditions employed in design 1 and absolute recoveries of each pesticide

\begin{tabular}{|c|c|c|c|c|c|c|c|c|}
\hline \multirow{2}{*}{ Assay } & \multicolumn{3}{|c|}{$\%(\mathrm{~m} / \mathrm{m} / \mathrm{m})$} & \multicolumn{5}{|c|}{ Absolute recovery / \% } \\
\hline & $\mathrm{CLF}^{\mathrm{a}}$ & $\mathrm{DCM}^{\mathrm{b}}$ & $\mathrm{ACN}^{\mathrm{c}}$ & DIA $^{d}$ & $\mathrm{DEA}^{\mathrm{e}}$ & $\mathrm{ATZ}^{\mathrm{f}}$ & DIU $^{g}$ & $\mathrm{TFB}^{\mathrm{h}}$ \\
\hline 1 & 100 & 0.000 & 0.000 & 51.1 & 83.4 & 99.3 & 99.5 & 67.7 \\
\hline 2 & 50.0 & 50.0 & 0.000 & $<0.48^{\mathrm{i}}$ & $<1.3^{\mathrm{i}}$ & $<0.82^{\mathrm{i}}$ & $<1.7^{\mathrm{i}}$ & $<1.3^{\mathrm{i}}$ \\
\hline 3 & 0.000 & 100 & 0.000 & 48.8 & 78.9 & 96.0 & 96.7 & 82.5 \\
\hline 4 & 70.0 & 20.0 & 10.0 & 52.3 & 80.1 & 96.9 & 96.3 & 59.6 \\
\hline 5 & 20.0 & 70.0 & 10.0 & 28.3 & 43.8 & 52.3 & 53.1 & 33.8 \\
\hline 6 & 0.000 & 50.0 & 50.0 & $<0.48^{\mathrm{i}}$ & $<1.3^{\mathrm{i}}$ & $<0.82^{\mathrm{i}}$ & $<1.7^{\mathrm{i}}$ & $<1.3^{\mathrm{i}}$ \\
\hline 7 & 10.0 & 0.000 & 90.0 & 30.5 & 48.2 & 78.8 & 82.9 & 53.9 \\
\hline 8 & 50.0 & 0.000 & 50.0 & 45.2 & 69.7 & 90.0 & 91.4 & 46.3 \\
\hline 9 & 50.0 & 10.0 & 40.0 & 49.0 & 73.0 & 94.6 & 95.0 & 59.3 \\
\hline 10 & 35.0 & 10.0 & 55.0 & 39.7 & 59.7 & 81.0 & 82.5 & 51.4 \\
\hline 11 & 20.0 & 10.0 & 70.0 & 52.3 & 77.5 & 103.0 & 100.4 & $<1.3^{\mathrm{i}}$ \\
\hline 12 & 20.0 & 40.0 & 40.0 & $39.3 \pm 1.2^{\mathrm{j}}$ & $104.5 \pm 2.2^{\mathrm{j}}$ & $83.4 \pm 1.4^{\mathrm{i}}$ & $91.9 \pm 1.2^{\mathrm{j}}$ & $45.0 \pm 0.65^{j}$ \\
\hline 13 & 35.0 & 25.0 & 40.0 & 50.8 & 74.6 & 96.0 & 94.0 & 52.7 \\
\hline 14 & 40.0 & 40.0 & 20.0 & 51.6 & 78.2 & 94.9 & 94.6 & 62.2 \\
\hline 15 & 30.0 & 20.0 & 50.0 & $48.8 \pm 2.3^{\mathrm{k}}$ & $72.7 \pm 3.1^{\mathrm{k}}$ & $91.7 \pm 4.2^{\mathrm{k}}$ & $95.1 \pm 4.5^{\mathrm{k}}$ & $64.3 \pm 5.8^{\mathrm{k}}$ \\
\hline
\end{tabular}

${ }^{\mathrm{a} C L F}$ : chloroform; ${ }^{\mathrm{b} D C M}$ : dichloromethane; ${ }^{\mathrm{ACCN}}$ : acetonitrile; ${ }^{\mathrm{d} D I A}$ : desisopropylatrazine; ${ }^{\mathrm{e} D E A}$ : desethylatrazine; ${ }^{\mathrm{f}} \mathrm{ATZ}$ : atrazine; ${ }^{\mathrm{g} D I U}$ : diuron;

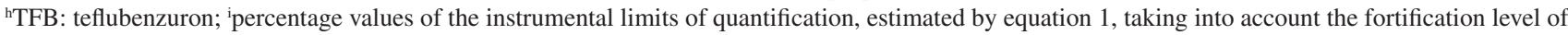
design $1\left(30.0 \mu \mathrm{g} \mathrm{L}^{-1}\right)$; ${ }^{\text {j}}$ standard deviation of absolute recovery (AR) for assay $12(\mathrm{n}=3)$; ${ }^{\mathrm{k}}$ standard deviation of AR for assay $15(\mathrm{n}=3)$. 
another design was performed to obtain valid empirical models close to the optimum region, as shown in Figure 1b. The assay 10 , which is displayed in red, was performed in triplicate.

\section{Design 2}

A simplex constrained mixture design was performed to evaluate in detail the best recovery sub-region, with lower and upper limits being delimited for the solvent mixture proportions. Thus, the chosen conditions were converted into pseudo-components, which simplifies the adjustment of the empirical models, ${ }^{44}$ so that the proportions varied from 0.000 to $100 \%$. The results for each condition (Figure 1b) are shown in Table 3.

Quadratic empirical models evaluated by ANOVA were well fitted for representing the absolute recovery rate of the analytes (DIA, DEA, ATZ, DIU, and TFB) as a function of the solvent proportions (extractor and disperser). In the case of TFB (less polar analyte), 12 assays from the design 1 were also considered to obtain the valid model. The parameters of the model are shown in Table 4.

The quadratic models obtained showed satisfactory percentage of explained variance, taking into account the percentage of maximum variance explainable by the model for all analytes. In addition, all regressions were significant at $95 \%$ of confidence level since the $\mathrm{MS}_{\text {Regression }} / \mathrm{MS}_{\text {residual }}\left(F_{\text {regression }}\right)$ ratio, where MS is the mean square, was higher than $F_{\text {critical }}$ (3.11 to DIA, DEA, ATZ, DIU models and 2.68 to TFB). Furthermore, no lack of fit was observed in any models, with $\mathrm{MS}_{\text {lack of fit }} / \mathrm{MS}_{\text {pure error }}\left(F_{\text {lack of fit }}\right)$ lower than $F_{\text {critical }}(19.32$ to DIA, DEA, ATZ and DIU models and 4.604 to TFB).

Besides, the residues produced by all empirical models were low and random, confirming the suitability of the models. Hence, response surfaces were built (Figure 3) to demonstrate the dependence of the analytes recoveries on the different proportions of solvents evaluated.

The best ratio of solvents for the simultaneous extraction of analytes can be determined by overlapping the response surfaces. This ratio is $47.5 \%$ CLF:5.00\% DCM: $47.5 \%$ ACN (point 15 of design 2), indicated by the white arrows in Figure 3. Under these conditions the absolute recoveries $(\mathrm{n}=3)$ were $49.4 \pm 1.4 \%$ for DIA, $73.2 \pm 1.2 \%$ for DEA, $95.1 \pm 2.4 \%$ for ATZ, $94.7 \pm 2.2 \%$ for DIU and $74.9 \pm 1.5 \%$ for TFB.

\section{Total solvent weight}

The influence of the amount by weight of the solvents mixture in the analytes recovery was conducted employing $0.800 ; 1.00 ; 1.25 ; 1.50 ; 1.75$ and $2.00 \mathrm{~g}$ of mixture solvents. These assays were performed at the proportion of best performance obtained by mixture modeling (47.5\% CLF, $5.00 \%$ DCM and $47.5 \%$ ACN). The absolute recoveries are shown in Figure 4.

Table 3. Absolute recoveries obtained for pesticides extraction in mixture design 2

\begin{tabular}{|c|c|c|c|c|c|c|c|c|}
\hline \multirow{2}{*}{ Assay } & \multicolumn{3}{|c|}{$\%(\mathrm{~m} / \mathrm{m} / \mathrm{m})$} & \multicolumn{5}{|c|}{ Absolute recovery / \% } \\
\hline & CLF & DCM & $\mathrm{ACN}$ & DIA & DEA & ATZ & DIU & TFB \\
\hline 1 & 70.0 & 0.000 & 30.0 & 44.6 & 69.6 & 81.1 & 85.0 & 56.7 \\
\hline 2 & 50.0 & 20.0 & 30.0 & 46.6 & 71.2 & 87.6 & 90.7 & 60.6 \\
\hline 3 & 30.0 & 40.0 & 30.0 & 43.5 & 65.6 & 78.5 & 80.8 & 53.4 \\
\hline 4 & 30.0 & 20.0 & 50.0 & 46.1 & 69.3 & 86.8 & 89.8 & 58.1 \\
\hline 5 & 30.0 & 0.000 & 70.0 & 39.8 & 62.5 & 86.1 & 90.7 & 57.3 \\
\hline 6 & 50.0 & 0.000 & 50.0 & 46.3 & 70.4 & 91.1 & 93.4 & 61.3 \\
\hline 7 & 60.0 & 5.00 & 35.0 & 47.1 & 72.3 & 88.3 & 90.3 & 63.8 \\
\hline 8 & 35.0 & 30.0 & 35.0 & 44.9 & 68.4 & 83.1 & 85.2 & 61.6 \\
\hline 9 & 35.0 & 5.00 & 60.0 & 42.7 & 65.9 & 86.2 & 88.4 & 58.2 \\
\hline 10 & 50.0 & 10.0 & 40.0 & $48.5 \pm 0.68^{\mathrm{a}}$ & $74.3 \pm 1.1^{\mathrm{a}}$ & $91.9 \pm 1.8^{\mathrm{a}}$ & $95.8 \pm 1.8^{\mathrm{a}}$ & $61.1 \pm 1.6^{\mathrm{a}}$ \\
\hline 11 & 40.0 & 20.0 & 40.0 & 41.9 & 62.8 & 77.7 & 80.3 & 54.7 \\
\hline 12 & 40.0 & 10.0 & 50.0 & 48.8 & 74.0 & 92.7 & 97.2 & 61.1 \\
\hline 13 & 35.0 & 17.5 & 47.5 & 45.4 & 69.4 & 87.1 & 90.6 & 58.8 \\
\hline 14 & 47.5 & 17.5 & 35.0 & 47.2 & 72.0 & 89.2 & 91.2 & 73.9 \\
\hline 15 & 47.5 & 5.00 & 47.5 & 48.1 & 73.4 & 92.3 & 96.1 & 74.1 \\
\hline
\end{tabular}

CLF: chloroform; DCM: dichloromethane; ACN: acetonitrile; DIA: desisopropylatrazine; DEA: desethylatrazine; ATZ: atrazine; DIU: diuron;

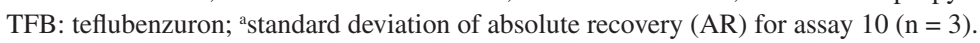


Table 4. ANOVA parameters for the quadratic empirical models obtained for the analytes by mixture modeling

\begin{tabular}{|c|c|c|c|c|c|}
\hline Source & Sum of squares (SS) & \multicolumn{2}{|c|}{ Degree of freedom $(\mathrm{df})$} & Mean square (MS) & $F$ value \\
\hline \multicolumn{6}{|c|}{ DIA } \\
\hline Regression (R) & 72.6 & 5 & & 14.5 & 4.24 \\
\hline Residual (r) & 37.8 & 11 & & 3.45 & \\
\hline Lack of fit (lof) & 36.8 & 9 & & 4.09 & 9 \\
\hline Pure error (pe) & 0.9 & 2 & & 0.5 & \\
\hline Total & 110.4 & 16 & & & \\
\hline Explained variance / \% & \multicolumn{5}{|c|}{50.3} \\
\hline Maximum explainable variance / \% & \multicolumn{5}{|c|}{65.8} \\
\hline \multicolumn{6}{|c|}{ DEA } \\
\hline Regression $(\mathrm{R})$ & 149.2 & 5 & & 29.84 & 3.43 \\
\hline Residual (r) & 95.6 & 11 & & 8.69 & \\
\hline Lack of fit (lof) & 93.2 & 9 & & 10.4 & 8.7 \\
\hline Pure error (pe) & 2.4 & 2 & & 1.2 & \\
\hline Total & 244.9 & 16 & & & \\
\hline Explained variance / \% & \multicolumn{5}{|c|}{43.2} \\
\hline Maximum explainable variance / \% & \multicolumn{5}{|c|}{61.0} \\
\hline \multicolumn{6}{|c|}{ ATZ } \\
\hline Regression (R) & 233.5 & 5 & & 46.70 & 3.683 \\
\hline Residual (r) & 139.5 & 11 & & 12.68 & \\
\hline Lack of fit (lof) & 133.1 & 9 & & 14.79 & 4.6 \\
\hline Pure error (pe) & 6.4 & 2 & & 3.2 & \\
\hline Total & 373.0 & 16 & & & \\
\hline Explained variance / \% & \multicolumn{5}{|c|}{45.6} \\
\hline Maximum explainable variance / \% & \multicolumn{5}{|c|}{62.6} \\
\hline \multicolumn{6}{|c|}{ DIU } \\
\hline Regression (R) & 260.5 & 5 & & 52.10 & 3.236 \\
\hline Residual (r) & 177.2 & 11 & & 16.10 & \\
\hline Lack of fit (lof) & 170.7 & 9 & & 18.97 & 5.8 \\
\hline Pure error (pe) & 6.5 & 2 & & 3.3 & \\
\hline Total & 437.7 & 16 & & & \\
\hline Explained variance / \% & \multicolumn{5}{|c|}{41.1} \\
\hline Maximum explainable variance / \% & \multicolumn{5}{|c|}{59.5} \\
\hline \multicolumn{6}{|c|}{ TFB } \\
\hline Regression (R) & 5522.9 & 5 & & 1104.6 & 9.4764 \\
\hline Residual (r) & 2447.9 & 21 & & 116.56 & \\
\hline Lack of fit (lof) & 2264.2 & 16 & & 141.51 & 3.853 \\
\hline Pure error (pe) & 183.7 & 5 & & 36.73 & \\
\hline Total & 7970.8 & 26 & & & \\
\hline Explained variance / \% & \multicolumn{5}{|c|}{62.0} \\
\hline Maximum explainable variance / $\%$ & \multicolumn{5}{|c|}{69.3} \\
\hline
\end{tabular}

DIA: desisopropylatrazine; DEA: desethylatrazine; ATZ: atrazine; DIU: diuron; TFB: teflubenzuron.

As seen in Figure 4, no significant differences were observed in the ARs of ATZ, DIU, and TFB when the total mass of solvent was varied, although smaller amounts of mixture solvent significantly reduced the recovery of DIA and DEA, which would increase their LODs and LOQs. Furthermore, larger quantities did not provide a significant increase in the absolute recovery rates. Hence, the total weight of $1.500 \mathrm{~g}$ was maintained (i.e., using $481 \mu \mathrm{L}$ of CLF, $56.6 \mu \mathrm{L}$ of DCM and $906 \mu \mathrm{L}$ of $\mathrm{ACN}$ ). In this optimized condition, the volume of the organic extract obtained was $772 \pm 19 \mu \mathrm{L}(\mathrm{n}=6)$, which allowed the drying time under nitrogen flow to be below $15 \mathrm{~min}$ in a system developed in the laboratory capable of drying 12 samples simultaneously. 

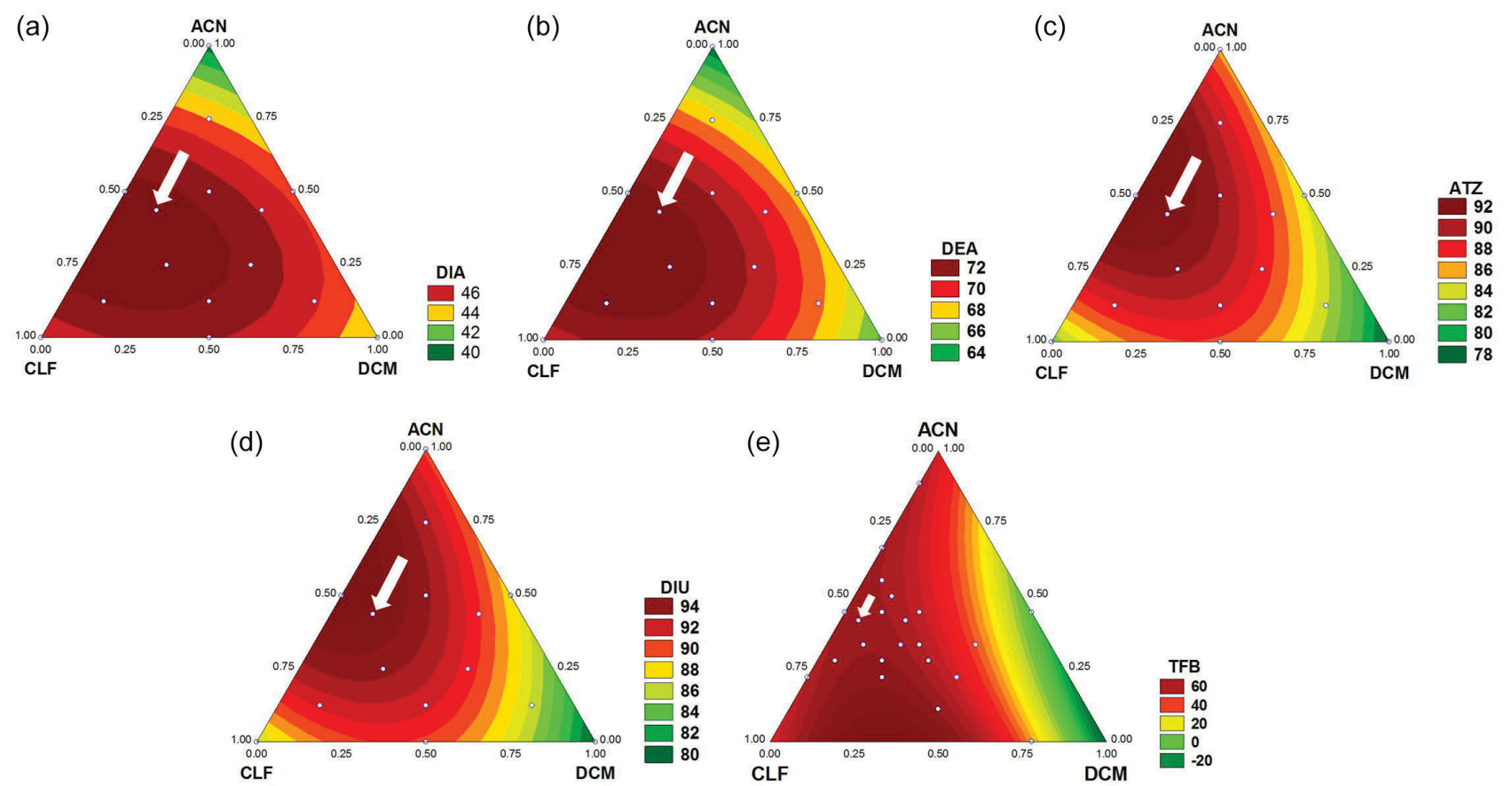

Figure 3. Level curves of the quadratic models to analytes absolute recovery as a function of solvent proportions (CLF:DCM:ACN). (a) DIA; (b) DEA; (c) ATZ; (d) DIU; (e) TFB.

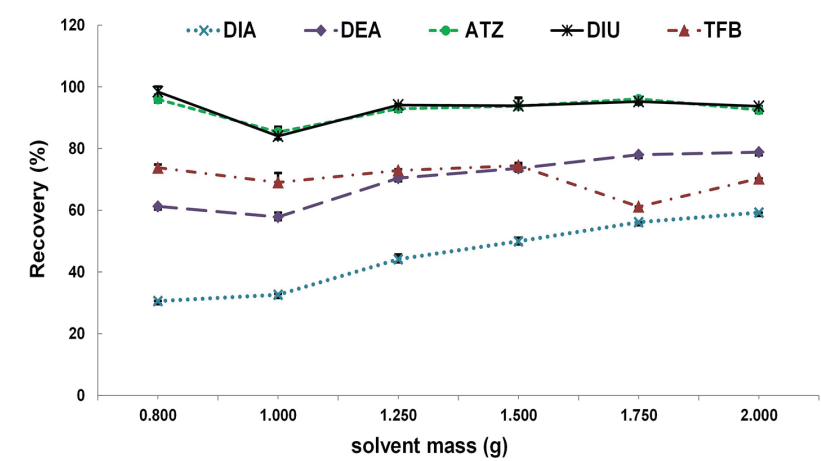

Figure 4. Total weight assessment of solvent employed in BS-DLLME.

Analytical performance of the method and real samples analysis

The optimal BS-DLLME conditions were applied to natural water samples collected in the state of Paraná at two different sites in the Tibagi River basin. The Tibagi River is $550 \mathrm{~km}$ long and limits one of the 16 hydrographic basins in the state of Paraná. Intensive agriculture represents the primary economic activity of this region, with emphasis on the crops of corn, soybeans, and wheat, ${ }^{47}$ in which the use of ATZ, DIU, and TFB is allowed in Brazil. These crops are the main responsible for the pesticide consumption in Paraná and utilized more than $70 \%$ of the pesticides marketed in the state between 2013 and $2015 .{ }^{48}$ Therefore, this region has a high potential for contamination of the water resources, making the monitoring of pesticides essential.
Table 5 summarizes the quantitative parameters of the BS-DLLME-LC-DAD obtained under optimized conditions in the ultrapure water and real samples (Iapó River and spring water). The enrichment factors (EFs) were estimated in ultrapure water by the ratio between the slopes of the calibration curves before (external standard calibration, Table 1) and after the BS-DLLME (matrixmatched calibration, Table 5).

The matrix-matched calibration curves were performed at six concentration levels $(n=3)$ and presented adequate linearity $(r>0.99)$ for all analytes in the respective LR. Furthermore, there were no notable differences between the curves obtained in real samples and in ultrapure water, confirming that the proposed method is not susceptible to the matrix effect in real samples.

Despite the lower EFs obtained in the BS-DLLME (8.029-19.82), this method showed $\mathrm{LOD}_{\mathrm{m}}$ and $\mathrm{LOQ}_{\mathrm{m}}$ values similar to those described in the literature, ${ }^{12,19,49,50}$ as shown in Table 6. In spite of providing high preconcentration factors, these methods have a high cost associated with the use of commercial cartridges or ionic liquids. Moreover, the method achieved LOQs similar to those obtained by GC-MS, known to be a more sensitive technique if compared to the DAD detection. In addition, the LOQ obtained for ATZ and DIU are lower than the limits established by the Brazilian legislation (2.0 and $90.0 \mu \mathrm{g} \mathrm{L}{ }^{-1}$, respectively). ${ }^{51,52}$ Thus, the proposed method is suitable and cheap for the determination of analytes in aqueous matrices, achieving merit parameters that are consistent with the literature. 
Table 5. Analytical features of the matrix-matched calibration in ultrapure water and real samples

\begin{tabular}{|c|c|c|c|c|c|}
\hline Parameter & $\begin{array}{c}\text { DIA } \\
(215 \mathrm{~nm})\end{array}$ & $\begin{array}{c}\text { DEA } \\
(215 \mathrm{~nm})\end{array}$ & $\begin{array}{c}\text { ATZ } \\
(223 \mathrm{~nm})\end{array}$ & $\begin{array}{c}\text { DIU } \\
(254 \mathrm{~nm})\end{array}$ & $\begin{array}{c}\text { TFB } \\
(200 \mathrm{~nm})\end{array}$ \\
\hline \multicolumn{6}{|c|}{ Ultrapure water } \\
\hline Slope & 0.05781 & 0.07237 & 0.11858 & 0.05489 & 0.07081 \\
\hline $\mathrm{r}$ & 0.9998 & 0.9992 & 0.9990 & 0.9999 & 0.9989 \\
\hline $\mathrm{LR} /\left(\mu \mathrm{g} \mathrm{L}^{-1}\right)$ & $0.50-100$ & $0.50-100$ & $0.50-100$ & $0.50-100$ & $5.0-100$ \\
\hline $\mathrm{LOQ}_{\mathrm{m}} /(\mu \mathrm{g} \mathrm{L}-1)$ & 0.049 & 0.14 & 0.21 & 0.45 & 1.2 \\
\hline $\mathrm{LOD}_{\mathrm{m}} /\left(\mu \mathrm{g} \mathrm{L}{ }^{-1}\right)$ & 0.015 & 0.042 & 0.062 & 0.13 & 0.36 \\
\hline $\mathrm{EF}$ & 8.029 & 15.24 & 18.24 & 19.82 & 14.54 \\
\hline \multicolumn{6}{|c|}{ Iapó River sample } \\
\hline Slope & 0.05881 & 0.07537 & 0.11668 & 0.05454 & 0.06958 \\
\hline $\mathrm{r}$ & 0.9999 & 0.9997 & 0.9998 & 0.9997 & 0.9946 \\
\hline $\mathrm{LR} /\left(\mu \mathrm{g} \mathrm{L}^{-1}\right)$ & $0.50-100$ & $0.50-100$ & $0.50-100$ & $0.50-100$ & $5.0-100$ \\
\hline $\mathrm{LOQ}_{\mathrm{m}} /\left(\mu \mathrm{g} \mathrm{L}^{-1}\right)$ & 0.15 & 0.22 & 0.29 & 0.17 & 1.8 \\
\hline $\mathrm{LOD}_{\mathrm{m}} /\left(\mu \mathrm{g} \mathrm{L}{ }^{-1}\right)$ & 0.046 & 0.066 & 0.087 & 0.05 & 0.54 \\
\hline \multicolumn{6}{|c|}{ Spring water } \\
\hline Slope & 0.5786 & 0.07179 & 0.1207 & 0.05534 & 0.06824 \\
\hline $\mathrm{r}$ & 0.9999 & 0.9998 & 0.9999 & 0.9999 & 0.9989 \\
\hline $\mathrm{LR} /\left(\mu \mathrm{g} \mathrm{L}^{-1}\right)$ & $0.50-100$ & $0.50-100$ & $0.50-100$ & $0.50-100$ & $5.0-100$ \\
\hline $\mathrm{LOQ}_{\mathrm{m}} /\left(\mu \mathrm{g} \mathrm{L}^{-1}\right)$ & 0.051 & 0.37 & 0.17 & 0.14 & 3.3 \\
\hline $\mathrm{LOD}_{\mathrm{m}} /\left(\mu \mathrm{g} \mathrm{L}^{-1}\right)$ & 0.015 & 0.11 & 0.050 & 0.042 & 0.998 \\
\hline
\end{tabular}

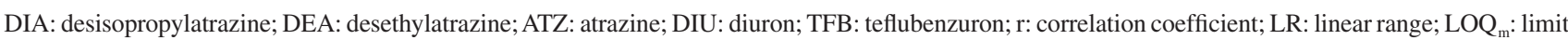
of quantification of the method; $\mathrm{LOD}_{\mathrm{m}}$ : limit of detection of the method; $\mathrm{EF}$ : enrichment factor.

Table 6. Comparison of the proposed method with other methods

\begin{tabular}{|c|c|c|c|c|c|c|}
\hline Analyte & Method & Sample volume / mL & $\mathrm{LOD}_{\mathrm{m}} /(\mu \mathrm{g} \mathrm{L}-1)$ & $\mathrm{LOQ}_{\mathrm{m}} /\left(\mu \mathrm{g} \mathrm{L}^{-1}\right)$ & $\mathrm{EF}$ & Reference \\
\hline DIA & \multirow{3}{*}{ SPE-GC-MS } & \multirow{3}{*}{100} & 0.04 & 0.2 & 100 & \multirow{3}{*}{50} \\
\hline DEA & & & 0.05 & 0.2 & 100 & \\
\hline ATZ & & & 0.02 & 0.2 & 100 & \\
\hline TFB & MR-IL-DLLME-LC-UV & 10 & 0.07 & 1 & 302 & 19 \\
\hline $\mathrm{DIU}$ & SUPRAS-LC-DAD & 10 & 0.13 & 0.43 & 48.5 & 49 \\
\hline DIA & \multirow{3}{*}{ SPE-LC-DAD } & \multirow{3}{*}{10} & 0.12 & 0.04 & \multirow{3}{*}{25} & \multirow{3}{*}{12} \\
\hline DEA & & & 0.09 & 0.03 & & \\
\hline ATZ & & & 0.09 & 0.03 & & \\
\hline DIA & \multirow{5}{*}{ BS-DLLME-LC-DAD } & \multirow{5}{*}{5} & 0.015 & 0.049 & 8.029 & \multirow{5}{*}{ proposed method } \\
\hline DEA & & & 0.042 & 0.14 & 15.24 & \\
\hline ATZ & & & 0.062 & 0.21 & 18.24 & \\
\hline DIU & & & 0.13 & 0.45 & 19.82 & \\
\hline TFB & & & 0.36 & 1.2 & 14.54 & \\
\hline
\end{tabular}

$\mathrm{LOD}_{\mathrm{m}}$ : limit of detection of the method; $\mathrm{LOQ}_{\mathrm{m}}$ : limit of quantification of the method; EF: enrichment factor; DIA: desisopropylatrazine; DEA: desethylatrazine; ATZ: atrazine; TFB: teflubenzuron; DIU: diuron; SPE-GC-MS: solid phase microextraction-gas chromatography coupled with mass spectrometry detection; MR-IL-DLLME-LC-UV: magnetic retrieval of ionic liquid-dispersive liquid-liquid microextraction-liquid chromatography coupled with ultraviolet absorbance detection; SUPRAS-LC-DAD: supramolecular solvent-based microextraction-liquid chromatography with diode array detection; SPE-LC-DAD: solid phase microextraction-liquid chromatography with diode array detection; BS-DLLME-LC-DAD: binary solvent-dispersive liquidliquid microextraction-liquid chromatography with diode array detection.

The trueness was evaluated using the absolute and relative recovery (RR) estimated by the ratio between the concentration obtained by matrix-matched calibration
$\left(\mathrm{C}_{\mathrm{mm}}\right)$ and the concentration of the fortification level $\left(\mathrm{F}_{\mathrm{L}}\right)$, according to equation 3 , at three spiking levels performed in triplicate. These results and the respective standard 
Table 7. Accuracy results for real samples analysis by BS-DLLME-LC-DAD method

\begin{tabular}{|c|c|c|c|c|c|c|c|}
\hline \multirow{2}{*}{ Analyte } & \multirow{2}{*}{$\mathrm{F}_{\mathrm{L}} /\left(\mu \mathrm{g} \mathrm{L}^{-1}\right)$} & \multicolumn{3}{|c|}{ Absolute recovery $\pm \mathrm{SD}^{\mathrm{a}} / \%$} & \multicolumn{3}{|c|}{ Relative recovery $\pm \mathrm{SD}^{\mathrm{b}} / \%$} \\
\hline & & Iapó River sample & Spring water & Ultrapure water & Iapó River sample & Spring water & Ultrapure water \\
\hline & 5.00 & $42.0 \pm 1.7$ & $37.7 \pm 1.2$ & $39.8 \pm 0.5$ & $106.1 \pm 4.2$ & $95.4 \pm 3.0$ & $99.7 \pm 1.3$ \\
\hline \multirow[t]{3}{*}{ DIA } & 50.0 & $40.1 \pm 0.3$ & $40.1 \pm 0.6$ & $40.4 \pm 1.6$ & $98.5 \pm 1.3$ & $99.9 \pm 0.6$ & $100.7 \pm 3.3$ \\
\hline & 100 & $39.7 \pm 0.9$ & $40.7 \pm 0.5$ & $40.8 \pm 0.4$ & $97.3 \pm 2.2$ & $101.4 \pm 1.2$ & $101.6 \pm 0.9$ \\
\hline & 5.00 & $75.5 \pm 1.3$ & $74.8 \pm 3.2$ & $78.7 \pm 2.8$ & $95.8 \pm 1.6$ & $97.5 \pm 4.2$ & $100.3 \pm 3.6$ \\
\hline \multirow[t]{3}{*}{ DEA } & 50.0 & $75.8 \pm 0.8$ & $73.4 \pm 1.3$ & $78.2 \pm 4.6$ & $95.5 \pm 1.0$ & $96.9 \pm 1.7$ & $102.3 \pm 4.9$ \\
\hline & 100 & $74.5 \pm 1.8$ & $74.5 \pm 1.3$ & $78.0 \pm 0.9$ & $94.0 \pm 2.3$ & $98.5 \pm 1.8$ & $102.3 \pm 1.2$ \\
\hline & 5.00 & $97.0 \pm 2.9$ & $95.6 \pm 2.5$ & $96.6 \pm 2.7$ & $84.8 \pm 3.2$ & $101.7 \pm 2.6$ & $104.7 \pm 2.9$ \\
\hline \multirow[t]{3}{*}{ ATZ } & 50.0 & $94.9 \pm 2.7$ & $93.5 \pm 1.1$ & $94.5 \pm 2.7$ & $101.2 \pm 2.9$ & $98.5 \pm 1.2$ & $101.3 \pm 2.9$ \\
\hline & 100 & $91.7 \pm 1.5$ & $95.0 \pm 0.1$ & $92.6 \pm 1.1$ & $98.8 \pm 1.6$ & $100.0 \pm 0.2$ & $98.2 \pm 1.2$ \\
\hline & 5.00 & $101.6 \pm 5.5$ & $99.9 \pm 2.7$ & $97.3 \pm 1.9$ & $104.0 \pm 5.6$ & $101.3 \pm 2.7$ & $98.7 \pm 1.9$ \\
\hline \multirow[t]{3}{*}{ DIU } & 50.0 & $100.0 \pm 1.4$ & $99.8 \pm 0.8$ & $101.0 \pm 3.0$ & $101.7 \pm 1.4$ & $100.1 \pm 0.8$ & $102.0 \pm 3.0$ \\
\hline & 100 & $97.2 \pm 2.1$ & $99.8 \pm 0.9$ & $97.5 \pm 2.6$ & $98.6 \pm 2.1$ & $99.9 \pm 0.9$ & $98.4 \pm 2.6$ \\
\hline & 5.00 & $56.3 \pm 2.1$ & $67.1 \pm 4.4$ & $55.0 \pm 1.1$ & $86.6 \pm 3.0$ & $88.5 \pm 6.3$ & $84.1 \pm 1.5$ \\
\hline \multirow[t]{2}{*}{ TFB } & 50.0 & $72.5 \pm 0.3$ & $71.2 \pm 2.0$ & $70.8 \pm 2.2$ & $102.3 \pm 0.4$ & $100.9 \pm 2.8$ & $98.3 \pm 3.1$ \\
\hline & 100 & $70.6 \pm 1.3$ & $70.6 \pm 0.6$ & $68.6 \pm 2.2$ & $99.3 \pm 1.9$ & $100.4 \pm 0.9$ & $94.8 \pm 3.1$ \\
\hline
\end{tabular}

a Standard deviation $(n=3)$ of the absolute recovery; ${ }^{b}$ standard deviation $(n=3)$ of the relative recovery. $\mathrm{F}_{\mathrm{L}}$ : fortification level; DIA: desisopropylatrazine; DEA: desethylatrazine; ATZ: atrazine; DIU: diuron; TFB: teflubenzuron.

deviation (SD) are shown in Table 7.

$\mathrm{RR}=\frac{\mathrm{C}_{\mathrm{mm}} \times 100}{\mathrm{~F}_{\mathrm{L}}}$

The method presented satisfactory RR for all analytes in all samples, with values within the acceptable range of $70-120 \%$. Higher SDs were also obtained in the lower concentrations, which was already expected due to the matrices complexity. However, the SDs for the determination of all analytes were lower than $6.3 \%$. Furthermore, the similarity of the RR among the samples indicated a low matrix effect, which also indicates the stability of the method to small $\mathrm{pH}$ variations since the $\mathrm{pH}$ of the Iapó River sample (6.70) is distinct from the spring water sample (6.43).

No significant matrix effect was observed on the absolute recovery rates of the analytes. The matrix effect was verified by a one-way ANOVA using the absolute recovery means (50.0 $\mu \mathrm{g} \mathrm{\textrm {L } ^ { - 1 }}$ of fortification level, $\left.\mathrm{n}=3\right)$ of three different groups of samples: Iapó River, spring water, and ultrapure water. According to this test, there are no statistically significant differences in the ARs among the different samples at $95 \%$ of confidence level since the $F$ values ( $\left.\mathrm{MS}_{\text {between groups }} / \mathrm{MS}_{\text {within groups }}\right)$ obtained for all analytes were lower than the $F_{\text {critical }}$ value, which is 5.14 for the df (degree of freedom) 2 and 6.

Although the sampling points are located in a region of great agricultural production, in the analysis of samples without fortification $(n=3)$ none of the analytes were found in concentrations above the $\mathrm{LOD}_{\mathrm{m}}$. In addition, no compounds eluted at the same retention time of the analytes in the blank samples, evidencing the selectivity of the method, as shown on the chromatograms in Figure 5.

Despite the presence of compounds eluting near the TFB, the peak is well resolved, evidencing the appropriate

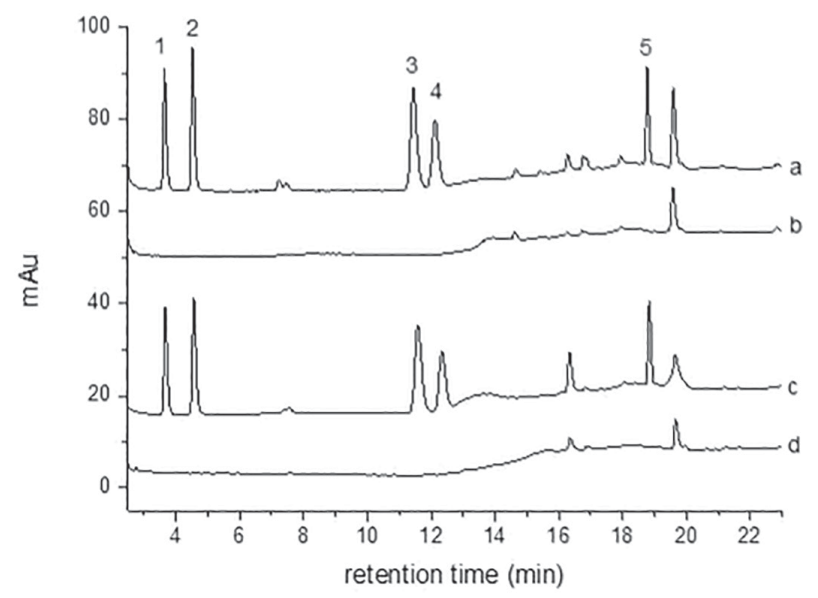

Figure 5. Typical LC-DAD $(215 \mathrm{~nm})$ chromatograms of real samples after BS-DLLME. Analyses of blank and fortified samples $\left(100 \mu \mathrm{g} \mathrm{L}^{-1}\right.$ of DIA and $50.0 \mu \mathrm{g} \mathrm{L}^{-1}$ of other analytes). (a) Fortified Iapó River sample; (b) blank Iapó River sample; (c) fortified spring water; (d) blank spring water. 1: Desisopropylatrazine; 2: desethylatrazine; 3 : atrazine; 4: diuron; 5: teflubenzuron. 
Table 8. Absolute recovery effects for the parameters evaluated by the Youden's test

\begin{tabular}{|c|c|c|c|c|c|}
\hline \multirow{2}{*}{ Parameter } & \multicolumn{5}{|c|}{ Effect } \\
\hline & DIA & DEA & ATZ & DIU & TFB \\
\hline Flow (A: $1.0 \mathrm{~mL} \mathrm{~min}^{-1} ;$ a: $0.9 \mathrm{~mL} \mathrm{~min}^{-1}$ ) & -3.57 & -4.72 & -5.97 & -11.12 & -6.78 \\
\hline Column temperature (B: $\left.40{ }^{\circ} \mathrm{C} ; \mathrm{b}: 42.5^{\circ} \mathrm{C}\right)$ & -1.92 & -2.98 & -3.15 & -0.56 & -6.31 \\
\hline Drying temperature (C: room; c: $30^{\circ} \mathrm{C}$ ) & 3.05 & 5.89 & 8.14 & 3.10 & -1.89 \\
\hline Stirring time (D: $30 \mathrm{~s} ; \mathrm{d}: 25 \mathrm{~s}$ ) & -0.51 & 0.13 & -2.50 & -0.68 & -0.42 \\
\hline Centrifugation time (E: $6 \mathrm{~min}$; e: $5 \mathrm{~min}$ ) & -3.04 & -4.64 & -4.74 & -4.85 & 3.58 \\
\hline Centrifugation speed (F: 4400 rpm; f: 4200 rpm) & 0.08 & 0.14 & 2.15 & 1.19 & 4.83 \\
\hline$\% \mathrm{NaCl}(\mathrm{G}: 10 \% \mathrm{~m} / \mathrm{v} ; \mathrm{g}: 9.5 \% \mathrm{~m} / \mathrm{v})$ & 2.48 & 4.94 & -9.49 & -4.95 & 10.37 \\
\hline $\mathrm{SD} \times t_{\text {student }}(\mathrm{df}=2 ; 95 \%$ of confidence level $)$ & 4.29 & 8.66 & 15.3 & 16.5 & 10.5 \\
\hline
\end{tabular}

DIA: desisopropylatrazine; DEA: desethylatrazine; ATZ: atrazine; DIU: diuron; TFB: teflubenzuron; SD: standard deviation $(n=6)$ for the analytes recoveries of Iapó River sample fortified with $50.0 \mu \mathrm{g} \mathrm{L}^{-1}$ of each compound; df: degree of freedom.

selectivity of the chromatographic method. The selectivity was also observed at $200 \mathrm{~nm}$, which is the wavelength susceptible to the absorption of many organic interferents present in the sample. The DAD spectra and the retention time of the pure standards prepared in acetonitrile:water $(40: 60 \mathrm{v} / \mathrm{v})$ were compared to those of the fortified real samples after the BS-DLLME. No difference between these parameters was observed, confirming the selectivity of the method.

The robustness of the proposed method was investigated using the Youden's test, ${ }^{53}$ employing the Iapó River sample fortified at $50.0 \mu \mathrm{g} \mathrm{L}^{-1}$. Seven parameters were evaluated and the values for the effects of each factor in the absolute recovery are shown in Table 8 .

The effects of the factors can be compared with the $\mathrm{SD}$, obtained using the intermediate precision, associated with the $t_{\text {student }}$ value for the respective replicates number. If the effects are lower than the $\mathrm{SD} \times t_{\text {student }}$, they are not significant. ${ }^{53}$ None of the effects obtained by the Youden's test (Table 8) was significant, indicating that the method is robust. Drying the extracts at $30{ }^{\circ} \mathrm{C}$ significantly reduced the time required in this step, and this condition was adopted in the optimized procedure, whereas the other conditions were maintained at the nominal levels of the Youden's test.

Based on the outcomes of the validation tests, the developed BS-DLLME-LC-DAD method is suitable for the determination of all analytes in natural waters samples.

\section{Conclusions}

The three component mixture design allowed the development of a fast, cheap and sensitive BS-DLLME method to the determination of pesticides, including two metabolites of atrazine, with log Kow ranging between 1.1 and 4.3. The use of acetonitrile as a disperser solvent and two extractor solvents (chloroform and dichloromethane) improved the recovery of the more polar analytes, allowing suitable recoveries for the simultaneous determination of compounds with a wide range of polarity. The LOQs values of the method for ATZ $\left(0.21 \mu \mathrm{g} \mathrm{L}^{-1}\right)$ and DIU $\left(0.45 \mu \mathrm{g} \mathrm{L}^{-1}\right)$ are, respectively, about 9.5 and 200 times lower than the limits established by the Brazilian legislation, indicating the capability of the method in detecting the pollutants in low concentrations. The method was validated and successfully applied to natural waters sampled in the state of Paraná, Brazil, without significant matrix effect.

\section{Acknowledgments}

The authors would like to express their gratitude to the CNPq (National Council for Scientific and Technological Development) and CAPES (Coordination for the Improvement of Higher Education Personnel) for their financial support and scholarship.

\section{References}

1. Jiang, J. Q.; Zhou, Z.; Sharma, V. K.; Microchem. J. 2013, 110, 292.

2. Giulivo, M.; de Alda, M. L.; Capri, E.; Barceló, D.; Environ. Res. 2016, 151, 251.

3. Pal, A.; He, Y.; Jekel, M.; Reinhard, M.; Gin, K. Y. H.; Environ. Int. 2014, 71, 46.

4. Agência Nacional de Vigilância Sanitária (ANVISA); Programa de Análise de Resíduos de Agrotóxicos em Alimentos (PARA) - Relatório de Atividades de 2011 e 2012; ANVISA: Brasília, 2013. Available at http://portal.anvisa.gov.br/ documents/111215/446359/Programa+de+An\%C3\%A1lise+d e+Res\%C3\%ADduos+de+Agrot $\%$ C3\%B3xicos+-+Relat $\% \mathrm{C} 3$ 
$\%$ B3rio+2011+e+2012+\%281\%C2\%BA+etapa\%29/d5e91ef04235-4872-b180-99610507d8d5, accessed in April 2018.

5. Associação Brasileira de Saúde Coletiva (ABRASCO); Dossiê ABRASCO - Um Alerta sobre os Impactos dos Agrotóxicos na Saúde; ABRASCO: Rio de Janeiro, 2012.

6. Instituto Brasileiro do Meio Ambiente e dos Recursos Naturais Renováveis (IBAMA); Boletim de Comercialização de Agrotóxicos e Afins - Histórico de Vendas - 2000 a 2012; IBAMA: Brasília, 2013.

7. Rocha, A. A.; Monteiro, S. H.; Andrade, G. C. R. M.; Vilca, F. Z.; Tornisielo, V. L.; J. Braz. Chem. Soc. 2015, 26, 2269.

8. Moreira, J. C.; Peres, F.; Simões, A. C.; Pignati, W. A.; Dores, E. C.; Vieira, S. N.; Strüssmann, C.; Mott, T.; Ciênc. Saúde Coletiva 2012, 17, 1557.

9. Machado, K. C.; Grassi, M. T.; Vidal, C.; Pescara, I. C.; Jardim, W. F.; Fernandes, A. N.; Sodré, F. F.; Almeida, F. V.; Santana, J. S.; Canela, M. C.; Nunes, C. R. O.; Bichinho, K. M.; Severo, F. J. R.; Sci. Total Environ. 2016, 572, 138.

10. Tankiewicz, M.; Fenik, J.; Biziuk, M.; TrAC, Trends Anal. Chem. 2010, 29, 1050.

11. Boulanouar, S.; Mezzache, S.; Combès, A.; Pichon, V.; Talanta 2018, 176, 465.

12. Cao, W.; Yang, B.; Qi, F.; Qian, L.; Li, J.; Lu, L.; Xu, Q.; J. Chromatogr. A 2017, 1491, 16.

13. Margoum, C.; Guillemain, C.; Yang, X.; Coquery, M.; Talanta 2013, 116, 1 .

14. Assoumani, A.; Margoum, C.; Chataing, S.; Guillemain, C.; Coquery, M.; J. Chromatogr. A 2014, 1333, 1.

15. Pinto, M. I.; Sontag, G.; Bernardino, R. J.; Noronha, J. P.; Microchem. J. 2010, 96, 225.

16. Martins, M. L.; Primel, E. G.; Caldas, S. S.; Prestes, O. D.; Adaime, M. B.; Zanella, R.; Sci. Chromatogr. 2012, 4, 35.

17. Caldas, S. S.; Gonçalves, F. F.; Primel, E. G.; Prestes, O. D.; Martins, M. L.; Zanella, R.; Quim. Nova 2011, 34, 1604.

18. Nagaraju, D.; Huang, S. D.; J. Chromatogr. A 2007, 1161, 89.

19. Zhang, J.; Li, M.; Yang, M.; Peng, B.; Li, Y.; Zhou, W.; Gao, H.; Lu, R.; J. Chromatogr. A 2012, 1254, 23.

20. Rezaee, M.; Assadi, Y.; Hosseini, M.-R. M.; Aghaee, E.; Ahmadi, F.; Berijani, S.; J. Chromatogr. A 2006, 1116, 1.

21. Leong, M.-I.; Fuh, M.-R.; Huang, S.-D.; J. Chromatogr. A 2014, 1335, 2.

22. Ahmad, W.; Al-Sibaai, A. A.; Bashammakh, A. S.; Alwael, H.; El-Shahawi, M. S.; TrAC, Trends Anal. Chem. 2015, 72, 181.

23. Primel, E. G.; Caldas, S. S.; Marube, L. C.; Escarrone, A. L. V.; Trends Environ. Anal. Chem. 2017, 14, 1.

24. Trujillo-Rodríguez, M. J.; Rocío-Bautista, P.; Pino, V.; Afonso, A. M.; TrAC, Trends Anal. Chem. 2013, 51, 87.

25. Gure, A.; Lara, F. J.; García-Campaña, A. M.; Megersa, N.; del Olmo-Iruela, M.; Food Chem. 2015, 170, 348.

26. Hrouzková, S.; Brišová, M.; Szarka, A.; J. Chromatogr. A 2017, 1506, 18.
27. Mansour, F. R.; Danielson, N. D.; Talanta 2017, 170, 22.

28. Kiarostami, V.; Rouini, M.-R.; Mohammadian, R.; Lavasani, H.; Ghazaghi, M.; Daru, J. Pharm. Sci. 2014, 22, 25.

29. Wang, X.; Wang, Y.; Zou, X.; Cao, Y.; Anal. Methods 2014, 6, 2384.

30. Farajzadeh, M. A.; Khoshmaram, L.; J. Chromatogr. A 2015 , 1379, 24.

31. Maham, M.; Karami-Osboo, R.; Kiarostami, V.; Waqif-Husain, S.; Food Anal. Methods 2013, 6, 761.

32. Pastor-Belda, M.; Garrido, I.; Campillo, N.; Viñas, P.; Hellín, P.; Flores, P.; Fenoll, J.; Food Chem. 2017, 233, 69.

33. Seabra, I. J.; Braga, M. E. M.; de Sousa, H. C.; J. Supercrit. Fluids 2012, 64, 9.

34. García-García, E.; Totosaus, A.; Meat Sci. 2008, 78, 406.

35. Bueno, L.; Quim. Nova 2008, 31, 306.

36. Handa, C. L.; de Lima, F. S.; Guelfi, M. F. G.; Georgetti, S. R.; Ida, E. I.; Food Chem. 2016, 197, 175.

37. Anarjan, N.; Jouyban, A.; Food Bioprod. Process. 2017, 103, 104.

38. Dorival-García, N.; Junza, A.; Zafra-Gómez, A.; Barrón, D.; Navalón, A.; Food Control 2016, 60, 382.

39. Statistica, version 7.0; StatSoft, Tulsa, USA, 2004.

40. Leandro, C.; Souza, V.; Dores, E. F. G. C.; Ribeiro, M. L.; J. Braz. Chem. Soc. 2008, 19, 1111.

41. Yoon, J.-Y.; Park, J.-H.; Han, Y.; Lee, K.-S.; J. Agric. Chem. Environ. 2012, 1, 10.

42. do Amaral, B.; de Araujo, J. A.; Peralta-Zamora, P. G.; Nagata, N.; Microchem. J. 2014, 117, 262.

43. Santos, L. F. S.; Souza, N. R. S.; Ferreira, J. A.; Navickiene, S.; J. Food Compos. Anal. 2012, 26, 183.

44. Neto, B. B.; Scarminio, I. S.; Bruns, R. E.; Como Fazer Experimentos - Pesquisa e Desenvolvimento na Ciência e na Indústria, $4^{\mathrm{a}}$ ed.; Bookman: Porto Alegre, 2010.

45. Instituto Nacional de Metrologia, Qualidade e Tecnologia (INMETRO); Orientação sobre Validação de Métodos Analíticos, DOQ-CGCRE-008; INMETRO: Rio de Janeiro, 2010. Available at http://www.inmetro.gov.br/Sidoq/ Arquivos/CGCRE/DOQ/DOQ-CGCRE-8_03.pdf, accessed in April 2018.

46. Anthemidis, A. N.; Ioannou, K. I. G.; Talanta 2009, 80, 413.

47. Secretaria de Estado do Meio Ambiente e Recursos Hídricos (SEMA); Bacias Hidrográficas do Paraná; SEMA: Curitiba, 2010. Available at http://www.meioambiente.pr.gov.br/arquivos/ File/corh/Revista_Bacias_Hidrograficas_do_Parana.pdf, accessed in April 2018.

48. Agência de Defesa Agropecuária do Paraná, Gerência de Sanidade Vegetal; Sistema de Monitoramento do Comércio e Uso de Agrotóxicos no Estado do Paraná, available at http://www.adapar.pr.gov.br/arquivos/File/GSV/Agrotoxicos/ RESULTADOS_PUBLICADOS/dados_siagro.xls, accessed on March 5, 2018. 
49. Scheel, G. L.; Tarley, C. R. T.; Microchem. J. 2017, 133, 650.

50. Min, G.; Wang, S.; Zhu, H.; Fang, G.; Zhang, Y.; Sci. Total Environ. 2008, 396, 79.

51. Ministério da Saúde (MS); Portaria MS No. 2914 de 12 de dezembro de 2011, Dispõe sobre os Procedimentos de Controle e de Vigilância da Qualidade da Água para Consumo Humano e seu Padrão de Potabilidade; Brasília, DF, 2011. Available at http://bvsms.saude.gov.br/bvs/saudelegis/gm/2011/ prt2914_12_12_2011.html, accessed in April 2018.

52. Conselho Nacional do Meio Ambiente (CONAMA); Resolução No. 357, de 17 de março de 2005, Dispõe sobre a Classificação dos Corpos de Água e Diretrizes Ambientais para o seu Enquadramento, bem como Estabelece as Condições e Padrões de Lançamento de Efluentes, e Dá Outras Providências; DOU: Brasília, Brasil, 2005. Available at http://www.mma.gov.br/port/ conama/legiabre.cfm?codlegi=459, accessed in April 2018.

53. Heyden, Y. V.; Nijhuis, A.; Smeyers-Verbeke, J.; Vandeginste, B. G. M.; Massart, D. L.; J. Pharm. Biomed. Anal. 2001, 24, 723.

Submitted: January 12, 2018

Published online: April 18, 2018 